weight of numbers at such international gatherings. Some further experimentation along the line of 'general discussion meetings' would seem to be required, though many such meetings suffer from the fact that too much time is taken up by long "introductory' papers which leave little opportunity or desire for general discussion afterwards. To achieve a more vivid interchange of ideas and information, it might perhaps be better to have at each session a single introductory review followed by informal discussion. It would also seem that such sessions require some preparatory work by which the organiser approaches individual colleagues in his field to ensure an adequate response.

It is perhaps doubtful whether there remains very much use for sectional sessions in which large numbers of individual papers follow one another, often with little or no connexion and little or no time for questions. If it is felt desirable to retain such sessions, members might at least be discouraged from including papers which have already been published in full. But criticisms such as these are a very minor matter compared with the good that comes from personal contact and the great stimulus that everyone can derive by challenging in private session his scientific friends and opponents.

At the closing session an invitation was received and warmly welcomed to hold the next, the Nineteenth International Physiological Congress, at Montreal in 1953.

\section{CONGRESS OF THE INTERNATIONAL ASSOCIATION FOR THE PROTECTION OF INDUSTRIAL PROPERTY}

$\mathrm{T}$

HE resolutions passed at the Congress of the International Association for the Protection of Industrial Property, held in Paris during June 1950, which have now been published, assume a wider significance in view of the measures being taken in other directions to effect the economic integration of Europe. The Association is an informal body comprising industrialists, patent agents, solicitors and barristers who are directly concerned with questions relating to invéntions, patents, trade marks and copyright. 'The expression "Industrial Property" is a convenient portmanteau phrase for describing commercial rights connected with international trade and industry in these matters.

The conception of a uniform international law in the limited field of industrial property is old. The Association was formed in the seventies of the past century with the object of remedying the insuperable difficulties which then faced a manufacturer or trader in one country in securing protection for his inventions or trade marks in foreign countries.

Prior to 1883 , there were a number of bipartite treaties entered into between various countries which specifically dealt inter alia with the protection of industrial property rights. In 1883, however, an International Convention for the Protection of Industrial Property was concluded in Paris, which laid down certain general principles to be applied by the member States in the manner best suited to their own systems of legislation so as to facilitate inter. national trade and to prevent all kinds of unfair trading. The Convention has been periodically revised, the last revision having been undertaken at a diplomatic conference in London in 1934.

The resolutions passed at the recent Congress of more than four hundred delegates from about forty countries are to be submitted to the Governments of all these countries, as the next revision of the Convention is due to be undertaken at a diplomatic conference in 1951. A summary of the more important resolutions which were passed unanimously is given under the three headings of general resolutions, resolutions dealing with patents, and resolutions dealing with trade marks, as follows.

General Resolutions. The Congress proposed the adoption in the Convention of an Article that "any dispute between two or a number of Convention countries concerning the interpretation or the applieation of the general Convention and of the restricted Conventions which is not settled by negotiation shall be referred to the International Court of Justice [at the Hague] for decision by the latter, unless the countries in question agree upon another method of settlement". In order to prevent the exercise of the power of the veto by one country in suppressing amendments to the Convention, it was resolved that there should be incorporated in the Convention and in the arrangements depending on it the declaration that all amendments approved by at least four-fifths of those voting should be adopted.

Resolutions dealing with Patents. A number of amendments dealing with priority rights in connexion with patents and designs were adopted. Thus, at any time up to the final grant of his patent, an applicant should have the right to divide his application, preserving for his new application the benefit of his original application.

Again, failure to work in a Convention country an invention which is the subject of a patent granted in that country, or the introduction by the patentee into that country of objects manufactured in another Convention country, shall not lead to revocation of the patent. However, in order to prevent abuses which might result from the exercise of the exclusive right conferred by the patent, each Convention country shall be entitled to impose legislative measures providing for the grant of compulsory licences to any qualified applicant. In no case should a compulsory licence be asked for before five years from the date of the application of the patent or three years from the grant, whichever shall be the longer. The grant of a licence should be refused if the patentee can legitimately justify his failure to work the invention. A resolution was adopted proposing a new measure to the effect that patents or certificates of addition shall be freely convertible into principal patents on the application of the patentee.

It is interesting to note that many of these amendments will have the effect of bringing many articles of the Convention more into line with the domestic patent law in Great Britain as set out in the Patent Act of 1949.

Resolution dealing with Trade Marks. The resolutions in regard to trade marks were probably of more immediate and of wider importance to present conditions of international trade. Questions relating to the assignment and licensing of trade marks have caused considerable commercial difficulties. The function of a trade mark is not to indicate ownership, but rather to guarantee that goods bearing a trade mark have certain standards of quality. 'The recognition of free assignability and licensing of trade 
marks is particularly necessary in international trade to-day where the owner must part with the title or use of his trade mark in order to be able to make it available in another country.

The Congress passed a resolution that the principle of free assignment of trade marks should be adopted by all Convention countries, subject to such limitations as the domestic law of each country requires to prevent deception of the public by the transfer of the mark. A further resolution was passed embodying the principle that persons other than the registered owner may use a trade mark provided that effective control of the use could be ensured by the proprietor, and subject again to such limitations as the domestic law of each country required, so as to prevent the use from deceiving the public.

Several other resolutions of lesser importance dealt with the prevention of unfair trading. When goods have been sold under a trade name which is a word in the vernacular of one of the countries, it may happen that a trader in another country may attempt to market similar goods in that foreign country under the name which is a translation of this word. This practice causes great difficulties and frequently leads to deception of the public. These difficulties would be overcome by the adoption of the principle that the Convention countries will accept and register, in one and the same operation, composite trade marks comprising the mark in the language of origin and its translation into other languages, each element of the composite mark being protected in itself.

These resolutions were supported in principle at the Conference of the International Bar Association held in July in Great Britain.

The adoption of these resolutions at the diplomatic conference of Governments will be a great step forward to the end that problems of international law in regard to industrial property may receive uniform solution in all countries which are party to the International Convention.

R. G. LlOXD

\section{ELEVENTH INTERNATIONAL CONGRESS OF THEORETICAL AND APPLIED LIMNOLOGY}

$\mathrm{T}$

${ }^{*} \mathrm{HE}$ Eleventh International Congress of Theoretical and Applied Limnology held in Belgium was attended by about eighty people representing seventeen different nations; but, despite the small number of participants, the vigorous exchange of opinion between all and sundry was a testimony to its great value. At the opening session, held in the fine assembly hall of the University of Ghent on the evening of August 16, the members were addressed by the president of the International Limnological Association (Dr. Gunnar Alm) and heard a lecture by the chairman of the Organising Committee (Prof. P. van Oye) on "The Beginnings of Limnology in Belgium". The six scientific sessions, at which upwards of forty papers on a wide range of topics were read, were held in the four university towns, Ghent, Brussels, Louvain and Liège, between August 17 and 23. Among many noteworthy contributions special mention may be made of those by Dr. Thomas (Zurich) on the nature of the monthly sediments deposited in certain Swiss lakes, by Dr. C. H. Mortimer (Windermere) on water movements in stratified lakes, by Prof. W. Rodhe (Uppsala) on a method of sampling and analysis of lake waters by ion exchangers, by Dr. M. Lefevre (France) on antagonisms between successive populations of freshwater algæ, by Prof. d'Ancona (Padua) on the changes induced by the environment on the marine plankton in the lagoons of Venice, and by Prof. Lenz (Plon) on problems concerning chironomid ecology, the last in particular leading to a lively discussion.

On the Sunday afternoon a visit was paid to the Congo Museum at Tervuren near Brussels, where the members of the congress were entertained to tea by the Director and his wife. Similar hospitality was afforded us on several other occasions. In the course of the journey from Brussels to Louvain the large centre for fish-culture at Linkebeek was visited under the guidance of the director of applied limnology, Dr. M. Huet, who also led a three-days tour of south-east Belgium during August 24-26, comprising visits to the principal rivers, to the Michel dam, to the thermal establishment at Spa, and to the grottoes at Han. At the concluding session held at Liège on August 23, a committee consisting of Drs. Mortimer, Ohle and Rodhe was appointed to study and coordinate and, if needs be, initiate, new methods for hydrobiological investigation. The next congress will be held in Cambridge during August 1953.

\section{F. E. Fritsch}

\section{AIRCRAFT-LANDING AIDS IN BAD VISIBILITY}

T a meeting held at Birmingham on September 5 of Section A (Mathematics and Physics) of the British Association, Mr. E. S. Calvert presented a paper entitled "Visual Aids for Landing in Bad Visibility, with Particular Reference to the Transition from Instrument to Visual Flight". Mr. Calvert said that during the past five years radio approach aids have been installed at all major airports to enable aircraft to land in conditions of bad visibility or low cloud. By means of these aids a pilot who is adequately trained in instrument-flying can align his aircraft with the runway and bring it down to a height of about $200 \mathrm{ft}$. without seeing the ground. The rest of the approach and landing, however, have to be made visually, and this means that the pilot has to make a rapid transition from instrument to visual flight when near the ground. At $200 \mathrm{ft}$. the aircraft is still about three-quarters of a mile from the end of the runway, and to bridge this gap a pattern of lights about 1,000 yd. long is laid down in the approach area. This pattern must be such that a pilot seeing only a portion of it can determine the aircraft's attitude, position and direction of motion, and the rates at which these are changing. The lights must be suitable for use by day as well as by night, and for this reason have to be of high intensity. The intensities being used at present are of the order of 100,000 candles.

During the radio portion of the approach, the pilot obtains his positional information either by listening to a voice in his earphones, or by looking at a meter on his instrument panel. From this he has to find the heading which will bring him on to the runway, a task which is particularly difficult when there is a cross-wind which varies with height. $\mathrm{He}$ also has to watch his flight instruments and manipulate the controls. His mind is therefore fully occupied when he sees the lights, and transition from instrument to 